University of Nebraska - Lincoln

DigitalCommons@University of Nebraska - Lincoln

7-1981

\title{
Reproduction in a Nebraska Sandhills Population of the Northern Prairie Lizard Sceloporus undulatus garmani
}

Royce E. Ballinger

University of Nebraska - Lincoln

Dale L. Droge

University of Nebraska - Lincoln

Steven M. Jones

University of Nebraska - Lincoln

Follow this and additional works at: https://digitalcommons.unl.edu/biosciherpetology

Part of the Biodiversity Commons, and the Zoology Commons

Ballinger, Royce E.; Droge, Dale L.; and Jones, Steven M., "Reproduction in a Nebraska Sandhills Population of the Northern Prairie Lizard Sceloporus undulatus garmani" (1981). Papers in Herpetology. 6.

https://digitalcommons.unl.edu/biosciherpetology/6

This Article is brought to you for free and open access by the Papers in the Biological Sciences at DigitalCommons@University of Nebraska - Lincoln. It has been accepted for inclusion in Papers in Herpetology by an authorized administrator of DigitalCommons@University of Nebraska - Lincoln. 


\section{The University of Notre Dame}

Reproduction in a Nebraska Sandhills Population of the Northern Prairie Lizard Sceloporus undulatus garmani

Author(s): Royce E. Ballinger, Dale L. Droge and Steven M. Jones

Source: American Midland Naturalist, Vol. 106, No. 1 (Jul., 1981), pp. 157-164

Published by: The University of Notre Dame

Stable URL: http://www.jstor.org/stable/2425145

Accessed: 10/05/2013 14:11

Your use of the JSTOR archive indicates your acceptance of the Terms \& Conditions of Use, available at http://www.jstor.org/page/info/about/policies/terms.jsp

JSTOR is a not-for-profit service that helps scholars, researchers, and students discover, use, and build upon a wide range of content in a trusted digital archive. We use information technology and tools to increase productivity and facilitate new forms of scholarship. For more information about JSTOR, please contact support@jstor.org. 


\title{
Reproduction in a Nebraska Sandhills Population of the Northern Prairie Lizard Sceloporus undulatus garmani
}

\author{
ROYCE E. BALLINGER, DALE L. DROGE and STEVEN M. JONES \\ School of Life Sciences, University of Nebraska-Lincoln, Lincoln 68588
}

\begin{abstract}
The reproductive cycle of Sceloporus undulatus was studied in western Nebraska. Females mature in the 1st year following hatching at a size of $45 \mathrm{~mm}$ SVL. Two clutches averaging 5.5 eggs each are produced. Egg sizes are similar to other grassland populations and contain approximately $650 \mathrm{~g}$-cal. per egg. Egg weight to body weight ratios of 0.33 were the highest which have been reported for any $S$. undulatus population. Variation in life history characteristics within and between grassland and eastern woodland habitat types are explicable given a knowledge of the growing season, predation intensity and demographic environment.
\end{abstract}

\section{INTRODUCTION}

Reproductive characteristics have been studied in a number of populations of Sceloporus undulatus (Crenshaw, 1955; Derickson, 1976; Ferguson and Bohlen, 1978; Marion, 1970a, 1970b; Sexton and Marion, 1974; Tinkle, 1972; Vinegar, 1975). Tinkle and Ballinger (1972) compared reproductive strategies in four widely spaced populations within the framework of variation in demographic data and life history strategies of the species. Ferguson et al. (1980) presented data on dynamics of an additional population and compared its life history traits with those from previous studies. They pointed out the three ecological regions to which $S$. undulatus has adapted, including eastern woodlands, grasslands and canyonlands. Of the 10 populations of $S$. undulatus which have been well studied, only one (eastern Kansas by Ferguson et al., 1980) represents a northern grassland form. That population exists on the distributional margin and undergoes considerable fluctuations. Some information on reproduction including an excellent analysis of the lipid cycle relative to reproduction was presented for a central Kansas population by Derickson (1976). Ferguson et al. (1980) concluded that more studies are needed on more populations before the geographic variation in life history patterns in $S$. undulatus is completely understood. Data presented here for a more northern grassland population advance this understanding by suggesting an adaptive basis for differences in geographic trends of reproduction and life history between grassland and eastern woodland regions and a proximal basis for the variation between the grassland populations.

The purposes of this study were to determine the reproductive cycle of a population of Sceloporus undulatus in western Nebraska and to compare its reproductive strategy with other populations. This population is farther $\mathrm{N}$ than any previous population which has been studied and is approximately 200 miles $\mathrm{S}$ of the northern distributional limit for the species in the central grasslands.

\section{Materials and Methods}

The study was conducted in the sandhills region of western Nebraska in southern Arthur and northern Keith counties; see Ballinger et al. (1979) and Jones and Droge (1980) for general descriptions of the area and its herpetofauna. The reproductive cycle described here is based on 88 females collected between 18 May and 12 August 1978 and 16 females collected on 28 April and 15 May 1979.

Specimens were autopsied in the laboratory and the number, size and weight of yolked ovarian follicles, oviducal eggs, corpora lutea and abdominal fat bodies were determined. Snout-vent length and body weight of the specimens were also noted. Caloric estimates of body and egg materials were made with a Phillipson microbomb calorimeter. Bodies and eggs were separated and dried to a constant weight at $100 \mathrm{C}$ in 
an oven and ground in a Wiley Mill (bodies) or with mortar and pestle. The gastrointestinal tract was excised from the body before drying and excluded from the analysis. Samples of bodies and eggs were ashed at $500 \mathrm{C}$ for $4 \mathrm{hr}$ in a muffle furnace to provide ash-free dry weight corrections to caloric estimates. Two aliquant samples per lizard body and per individual clutch were used for caloric estimates using standard calorimetry procedures (Phillipson, 1964). The percentage of total body lipids was determined by ethyl ether extraction for $4 \mathrm{hr}$ using a Labconco-Goldfish fat extractor.

In addition to samples obtained for reproductive autopsy, lizards were marked and periodically recaptured on a 150 X 150 m study plot located on Arapaho Prairie in June of 1977 and May-August of 1978 (see Jones and Droge, 1980, for description of area). These observations confirmed age at maturity and provided evidence of clutch frequency.

\section{Results}

Size and age at maturity. - The size of females ranged from 35-67 mm snout-vent length (SVL). Reproductive females (those with yolked follicles and/or oviducal eggs) averaged $54.5 \mathrm{~mm}$ SVL (Fig. 1). A minimum $45 \mathrm{~mm}$ SVL is the approximate size at maturity although one female measuring $44 \mathrm{~mm}$ SVL was reproductive on 17 May 1978. Between mid-May and late June, all females above $45 \mathrm{~mm}$ SVL were reproductive whereas $89 \%$ of those below $45 \mathrm{~mm}$ SVL were nonreproductive.

Females mature in their first reproductive season after birth at an age of 9-10 months. All 42 females observed on the mark-recapture plot in 1978 were greater than $45 \mathrm{~mm}$ after 31 May. A single female (44 mm SVL) collected 23 June 1978 (Fig. 1) has been recorded which may not have matured in its 1 st year. This individual would represent less than $1 \%$ of the female population.

Follicular development and ovulation. - Immature ovaries contained numerous (8-15) transparent gray to translucent white follicles $<1.5 \mathrm{~mm}$ in diam. Yolked follicles were present in females between late April and late June as well as in one female collected 8 July. Vitellogenesis appears to begin in mid- to late April in larger females and late April to early May in smaller females. Yolked follicles varied from 1.7 to $7.5 \mathrm{~mm}$ in diam.

The earliest date of ovulation was noted by presence of oviducal eggs in a female collected 28 April 1979. Ovulation was well under way by mid-May in 1978 (Fig. 1) when seven of 12 females contained oviducal eggs. Corpora lutea persisted for a very brief time and many of the females were beginning to develop a second set of yolked follicles at which time corpora lutea disappeared. A high frequency of females with oviducal eggs was observed in mid-June and smaller females had eggs in early July (Fig. 1).

Lipid cycle. - Lipids which are stored in abdominal fat bodies are important to production of eggs in lizards (Hahn and Tinkle, 1965). Derickson (1976) suggested that the relatively high total lipid content of Sceloporus undulatus was an adaptation to permit rapid reproduction earlier in the season than would be possible without the lipid reserves. After 10 June body lipid reserves increased steadily (Fig. 2). The lowest lipid levels probably occur in May, which would coincide with the period of maximum vitellogenesis.

Reproductive potential. - Reproductive potential as used here refers to the total number of eggs produced by a female in one reproductive season and thus depends on clutch size and the number of clutches per season.

Clutch size varies with body size (Fig. 3) with approximately one egg added for each $5 \mathrm{~mm}$ of SVL. There was no significant difference in size of first and second clutches in 1978 (5.84 vs. 5.38 eggs) or between these and the first clutch of 1979 (5.33 eggs). The average size for all $(\mathrm{n}=63)$ clutches was $5.55( \pm 0.422= \pm 2 \mathrm{sE})$.

Frequency of oviposition and numbers of clutches produced can be determined only by frequent recapture and examination of individually marked females. Presence of 
oviducal eggs and yolked follicles in some females (Fig. 1) is evidence that this population of Sceloporus undulatus produces multiple clutches. Records from the markrecapture study indicated two periods of frequent oviposition as indicated by weight losses. These periods were early June and late June-early July. Therefore, two clutches appeared to be produced in both 1978 and 1979. One large female with large yolked follicles, collected 8 July 1978, may have been producing a third clutch although such an occurrence is probably rare.

Given two clutches per season averaging 5.5 eggs each yields a yearly reproductive potential of 11 eggs.

Energetics and reproductive effort. - The amount of energy expended on reproduction is an important parameter in the evolution of life history features (Tinkle, 1969; Tinkle $e t$ al., 1970; Tinkle and Hadley, 1975). Measurement of reproductive effort requires extensive knowledge of the total energy budget (Hirshfield and Tinkle, 1975), but caloric

\section{8}

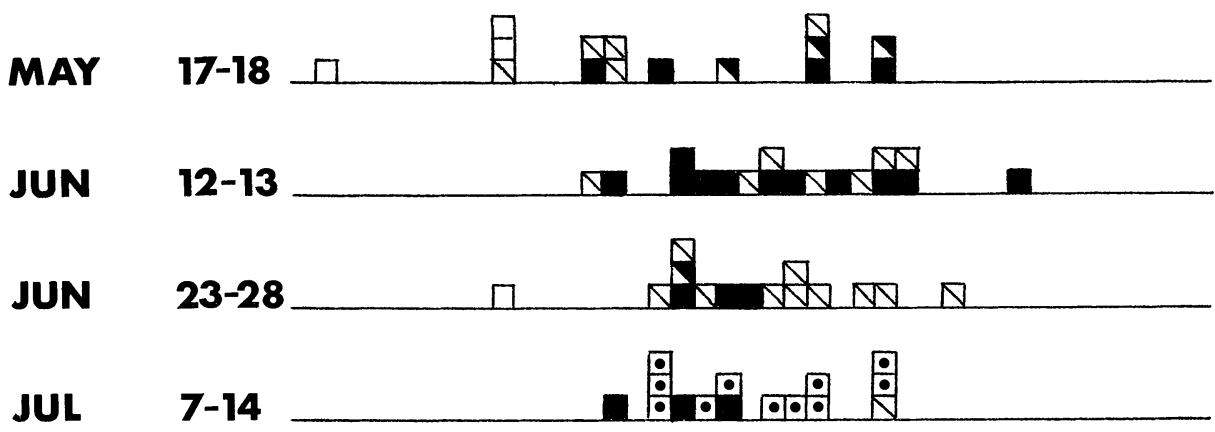

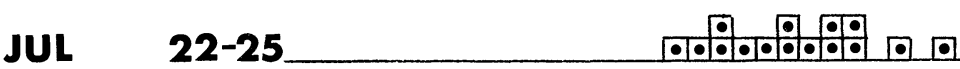
AUG
$11-12$
निन्निनण० 口]

1979

APR $\quad 28$

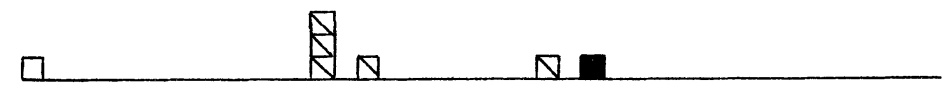

MAY

15

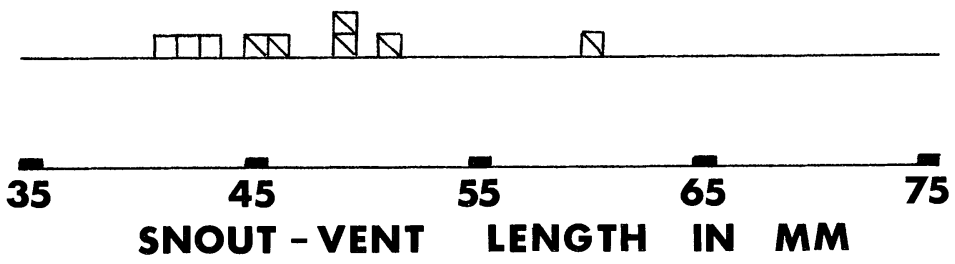

Fig. 1. - Relationship between size and reproductive condition of female Sceloporus undulatus, each square represents one animal with open squares=nonreproductives; diagonal line = ovarian follicles; solid square = oviducal eggs; one-half solid square = ovarian follicles and oviducal eggs; dot $=$ postreproductive 
estimates of eggs and egg/body weight ratios can provide useful information for comparative purposes (Williams, 1966).

Table 1 gives indices of reproductive effort based on the ratio of wet or dry weights of eggs to total weight and egg calories to total calories. These indices express the percentage of material (weight or energy) which is put into reproduction at one instant prior to oviposition. The wet ratios are smallest due to differential water content of bodies and eggs. The dry weight and caloric estimates are not significantly different; thus, either one could be used as indices of instantaneous reproductive effort. Bodies averaged $5700 \mathrm{cal}$ per $\mathrm{g}$ of ash-free dry weight (AFDW) and eggs averaged $6379 \mathrm{cal}$ per g AFDW. Weights of eggs averaged $0.234 \mathrm{~g}$ wet and $0.102 \mathrm{~g}$ dry, and thus contained about $56 \%$ water and 653 calories. There was no difference in size or caloric content of eggs in the first compared to the second clutch. Likewise, there was no difference in the indices of reproductive effort for first and second clutches (Table 1). During one reproductive season one Sceloporus undulatus in this population expends ca. 7200 calories in the production of eggs or about one and one-half times the caloric value maintained in the soma.

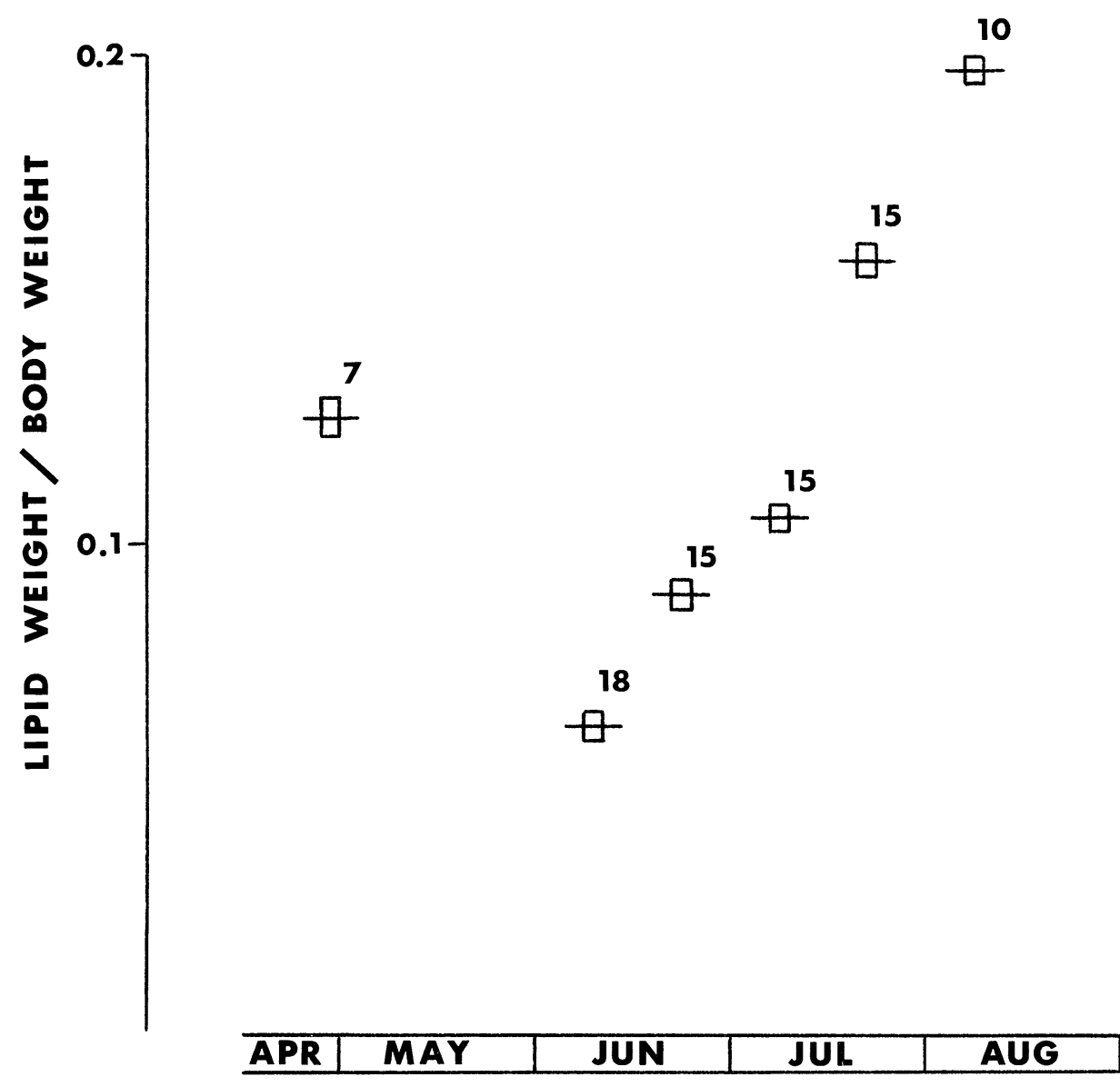

Fig. 2. - Total lipid weight expressed as a proportion of total body weight in female Sceloporus undulatus. Horizontal lines $=$ means; vertical bars are $\pm 2 \mathrm{sE}$; numerals above bars are sample size 


\section{Discussion}

Reproductive characteristics of this northern plains population of Sceloporus undulatus differ in several regards from other populations which have been studied (Table 2 ). It had the smallest clutch size, smallest body size and highest clutch weight to body weight ratio of the 11 populations studied. Both egg size and age at maturity were similar to other grassland populations.

Ferguson et al. (1980) called attention to some of the important trends in life history and reproductive characteristics within and between the "habitat forms" of Sceloporus undulatus. In particular, they noted that the N-S trend in life history pattern of the grassland form is reversed from that observed in the eastern woodland's and canyonland's forms. Our data support their conclusions and extend the northern trend in the grassland populations of decreasing body size, decreasing clutch size and increasing ratio of clutch weight to body weight. Some of the differences can be attributable to proximal factors occurring within the habitat types, but differences in geographical trends suggest an adaptive variation between the grassland and woodland forms.

Within the grassland populations, the differences in reproductive characteristics of the Nebraska population can be related to proximate responses to the northern plains environment. The smaller adult body size of northern grassland lizards probably reflects the decreased length of the growing season which approximates 6 months in Nebraska compared to 9 months in Texas and New Mexico. The shorter season also restricts the number of clutches. This reduction in reproductive potential, which includes small clutches resulting from smaller body size, is probably offset by increased

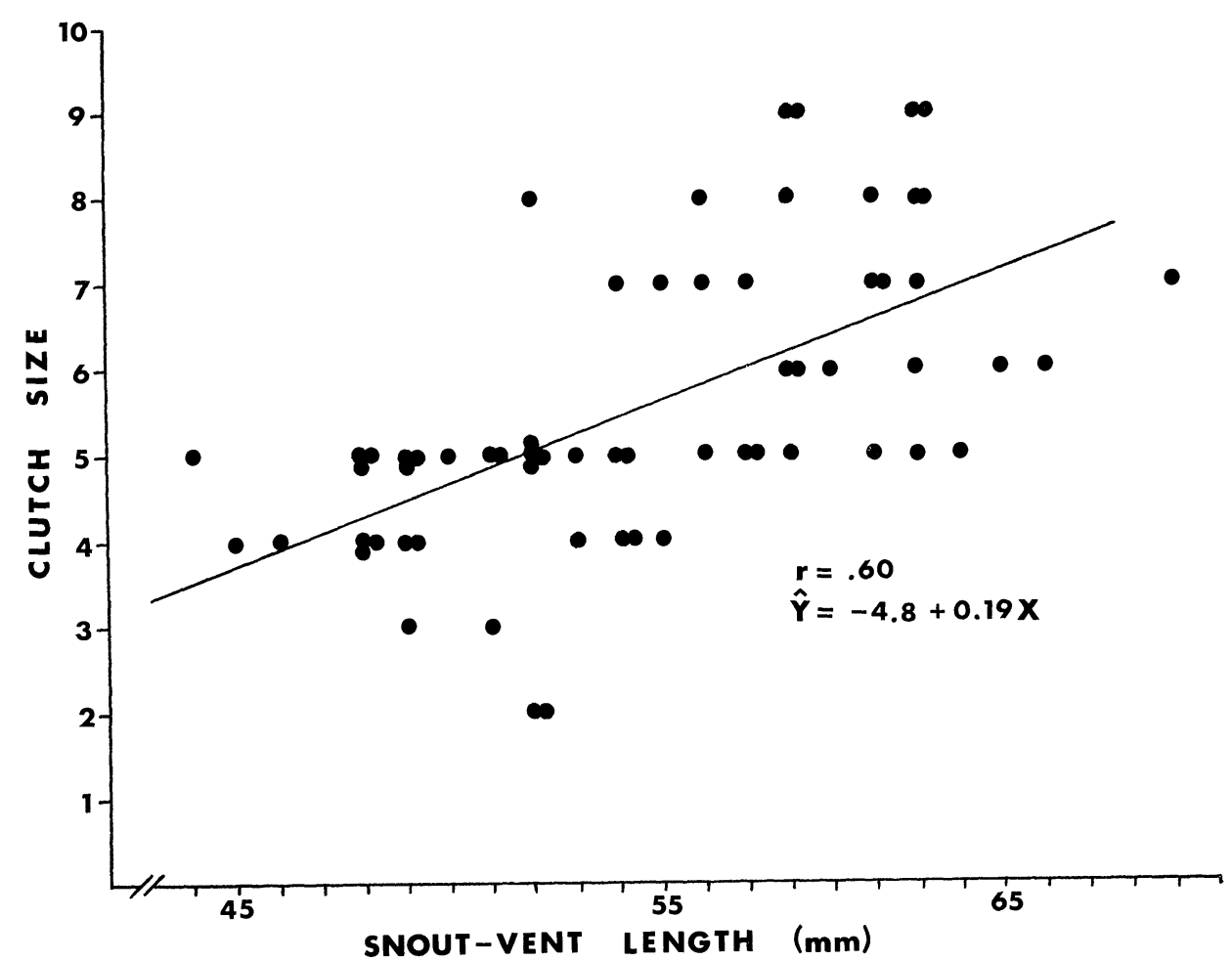

Fig. 3.-Relationship between clutch size and snout-vent length in Sceloporus undulatus. Regression equation and correlation co-efficient are given 
survivorship of both adults and hatchlings and perhaps greater hatching success. Although mortality data are not yet available, several factors suggest that it will be less in the northern population. First, the shorter season would decrease exposure to predators. Secondly, frequency of regenerated tails is considerably less in our Nebraska population than in Vinegar's (1975) study (4\% compared to $36 \%$ ). Frequency of regenerated tails has been used as an index of predator pressure (Pianka, 1970; Tinkle and Ballinger, 1972), but see Schoener (1979). Climatic conditions favorable for growth (long, warm days) and hatching (sufficient subsoil moisture), as well as relatively good food resources of the Great Plains compared to fluctuating resources of the desert Southwest (Ballinger, 1977), probably further insure the reproductive success of northern grassland populations. As a result of favorable growth and reproductive conditions, there has not been the adaptive shift to delayed maturity in northern grassland populations as has occurred in northern populations of both eastern woodlands and canyonlands.

A comparison between the Nebraska and Ohio (see Tinkle and Ballinger, 1972) populations reveals the possible basis for differences in adaptive strategy between grassland and woodland forms. The populations are similar in number of clutches (2), length of growing season ( 6 months) and predation intensity as indicated by tail

TABLE 1. - Estimates of reproductive effort (mean $\pm 2 \mathrm{sE}$ ) using three different indices. Numbers in parentheses indicate sample size

\begin{tabular}{|c|c|c|c|}
\hline & Wet clutch weight & Dry clutch weight & Clutch calories \\
\hline & Total wet weight & Total dry weight & Total calories \\
\hline First clutch & $.255 \pm 0.019(15)$ & $.395 \pm 0.033(12)$ & $.422 \pm 0.034(12)$ \\
\hline Second clutch & $.226 \pm 0.022(8)$ & $.362 \pm 0.048(8)$ & $.388 \pm 0.048$ (8) \\
\hline All clutches & $.245 \pm 0.015(23)$ & $.382 \pm 0.028(20)$ & $.408 \pm 0.028(20)$ \\
\hline
\end{tabular}

TABLE 2. - Comparison of reproductive characteristics in populations of Sceloporus undulatus

\begin{tabular}{|c|c|c|c|c|c|c|c|c|}
\hline \multirow[b]{3}{*}{ Eastern woodlands } & \multicolumn{2}{|c|}{$\begin{array}{c}\text { SVL of } \\
\text { adult } \\
\text { females }\end{array}$} & \multirow{2}{*}{\multicolumn{5}{|c|}{ 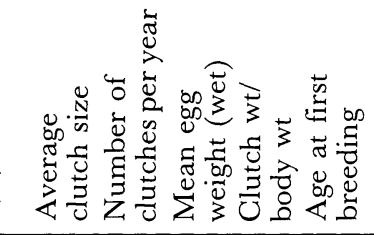 }} & \multirow[b]{2}{*}{ Source } \\
\hline & \multicolumn{2}{|c|}{ Min. Av. } & & & & & & \\
\hline & & & & & & & & \\
\hline Ohio & 66 & 75 & 11.8 & 2 & .35 & .25 & 2 & Tinkle and Ballinger, 1972 \\
\hline Missouri & 53 & 67 & $11(8.9)^{*}$ & 2 & .38 & .24 & $1-2$ & Marion, 1970b \\
\hline Georgia & 52 & 62 & 7.6 & 3 & -- & -- & 1 & Crenshaw, 1955 \\
\hline South Carolina & 55 & 63 & 7.4 & 3 & .33 & .23 & 1 & Tinkle and Ballinger, 1972 \\
\hline \multicolumn{9}{|l|}{ Grasslands } \\
\hline Nebraska & 44 & 55 & 5.5 & 2 & .23 & .33 & 1 & this study \\
\hline Kansas & 47 & 57 & 7.0 & 2 & .26 & .28 & 1 & Ferguson et al., 1980 \\
\hline Texas & 47 & 57 & 9.5 & 3 & .22 & .27 & 1 & Tinkle and Ballinger, 1972 \\
\hline Lordsburg, N.M. & 54 & 68 & 9.9 & 4 & .24 & .21 & 1 & Vinegar, 1975 \\
\hline \multicolumn{9}{|l|}{ Canyonlands } \\
\hline Colorado & 58 & 70 & 7.9 & 2 & .42 & .23 & 2 & Tinkle and Ballinger, 1972 \\
\hline Utah & 58 & 69 & 6.3 & 3 & .36 & .21 & $1-2$ & Tinkle, 1972 \\
\hline Pinos Altos, N.M. & 53 & 63 & 7.2 & $2-3$ & .29 & .22 & $1-2$ & Vinegar, 1975 \\
\hline
\end{tabular}

*first clutch (second clutch) 
regeneration frequency (less than 10\%). The Ohio lizards have a larger adult body size, mature later and have a larger size of clutch. The early maturity in the Nebraska lizards perhaps precludes their attaining the large body size of Ohio lizards. Early maturity is possible in Nebraska because of the favorable food resources and the long days available for activity. This long daily activity period (ca. 7 a.m. to 8 p.m., Ballinger, unpubl. data) provides extra time for growth and accelerates hatching time. Daily activity periods in the woodland habits are reduced (ca. 8-9 a.m. to 5-6 p.m., Ballinger, unpubl. data) for this heliothermic species because of shadows produced by the forest structure. Hatching occurs in late July and August in Nebraska, whereas it occurs in late August and September in Ohio (Tinkle and Ballinger, 1972). The earlier hatching date and the long days for activity permit sufficient time for growth to a mature size in 1 year in Nebraska. It may also result in higher mortality which would provide the demographic pressure favoring early maturity. Final assessment of these differences must await the demographic studies currently in progress. The geographic trends noted by Ferguson et al. (1980) in the different habitat forms do not appear inconsistent with the mechanisms of evolutionary adaptations proposed by Tinkle and Ballinger (1972).

Acknowledgments. - This research was supported in part by NSF grants SER 77-06931 and DEB 77-24477. We thank J. Nietfeldt for field and laboratory assistance and B. Nickol for the laboratory space at Cedar Point Biological Station. We are indebted to the Nature Conservancy for providing Arapaho Prairie as a primary controlled-access research site. We thank an anonymous reviewer for suggesting we expand the discussion.

\section{Literature Gited}

Ballinger, R. E. 1977. Reproductive strategies: food availability as a source of proximal variation in a lizard. Ecology, 58:628-635.

, J. D. LYNGH AND P. H. Cole. 1979. Distribution and natural history of amphibians and reptiles in western Nebraska with ecological notes on the herpetiles of Arapaho Prairie. Prairie Nat., 11:65-74.

Crenshaw, J. W. 1955. The life history of the southern spiny lizard, Sceloporus undulatus undulatus Latreille. Am. Midl. Nat., 54:257-298,

Derickson, W. K. 1976. Ecological and physiological aspects of reproductive strategies in two lizards. Ecology, 57:445-458.

Ferguson, G. W. and C. H. Bohlen. 1978. Demographic analysis: a tool for the study of natural selection of behavioral traits, p. 227-243. In: N. Greenberg and P. D. MacLean (eds.). Behavior and neurology of lizards. NIMH.

AND H. P. Woolley. 1980. Sceloporus undulatus: comparative life history and regulation of a Kansas population. Ecology, 61:313-322.

Hahn, W. E. AND D. W. TinkLe. 1965. Fat body cycling and experimental evidence for its adaptive significance to ovarian follicle development in the lizard Uta stansburiana. J. Exp. Zool., 158:79-86.

Hirshfield, M. F. AND D. W. Tinkle. 1975. Natural selection and the evolution of reproductive effort. Proc. Natl. Acad. Sci. USA, 72:2227-2231.

Jones, S. M. AND D. L. Droge. 1980. Home range size and spatial distributions of two sympatric lizard species (Sceloporus undulatus, Holbrookia maculata) in the Sand Hills of Nebraska. Herpetologica, 36:127-132.

Marion, K. R. 1970a. Temperature as the reproductive cue for the female fence lizard Sceloporus undulatus. Copeia, 1970:562-564.

1970b. The reproductive cycle of the fence lizard, Sceloporus undulatus, in eastern Missouri. Ph.D. Dissertation, Washington University, St. Louis. 212 p.

Phillipson, J. 1964. A miniature bomb calorimeter for small biological samples. Oikos, 15:130-139.

Pianka, E. R. 1970. Comparative autecology of the lizard Cnemidophorus tigris in different parts of its geographic range. Ecology, 51:703-720.

Schoener, T. W. 1979. Inferring the properties of predation and other injuryproducing agents from injury frequencies. Ibid., 60:1110-1115.

Sexton, O. J. and K. R. Marion. 1974. Duration of incubation of Sceloporus undulatus eggs at constant temperature. Physiol. Zool., 47:91-98. 
Tinkle, D. W. 1969. The concept of reproductive effort and its relation to the evolution of life histories of lizards. Am. Nat., 103:501-516. 1972. The dynamics of a Utah population of Sceloporus undulatus. Herpetologica, 28:351-359.

AND R. E. BAllinger. 1972. Sceloporus undulatus: a study of the intraspecific comparative demography of a lizard. Ecology, 53:570-584.

AND N. F. HAdley. 1975. Lizard reproductive effort: caloric estimates and comments on its evolution. Ibid., 56:427-434.

H. Wilbur And S. Tilley. 1970. Evolutionary strategies in lizard reproduction. Evolution, 24:55-74.

Vinegar, M. B. 1975. Life history phenomena in two populations of the lizard Sceloporus undulatus in southwestern New Mexico. Am. Midl. Nat., 93:388-402.

Williams, G. G. 1966. Adaptation and natural selection. Princeton Univ. Press, Princeton, New Jersey. 307 p.

Submitted 23 June 1980

Agcepted 21 November 1980 